\title{
JOURNAL.RU
}

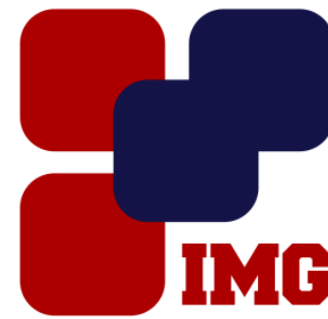
IVANOY Management
GROUP

\author{
Юшкова Е.И. ${ }^{1}$, Ярован Н.И. ${ }^{2}$, Полехина Н.Н. ${ }^{1}$ \\ ${ }^{1}$ ФГБОУ ВО «Орловский государственный университет им. И.С. Тургенева» \\ ${ }^{2}$ ФГБОУ ВО «Орловский государственный аграрный университет им. Н.В. Парахина» \\ Орел, Россия
}

doi: $10.18411 / 1 \mathrm{j}-31-07-2017-33$

idsp 000001:1j-31-07-2017-33

\section{Зависимость антиоксидантной активности плодов боярышника обыкновенного (Crataegusrhipidofilla) от сроков хранения}

\section{Аннотация}

Цель исследования - количественное определение содержания флавоноидов в плодах боярышника обыкновенного, оценка их сохранности в течение 12 и 24 месяцев; определение антиоксидантной активности разных препаративных форм при длительных сроках хранения.

Ключевые слова: флавоноиды, антиоксидантная активность.

\section{Abstract}

The main purposes of the study were quantification of the amount of flavonoids in hawthorn fruit (Crataegusrhipidofilla);assessment of quality of the fruit during 12 and 24 months; assessment of antioxidant activity during long periods of storage.

Key words: flavonoids, antioxidant activity.

Растения рода боярышник - Crataegus- содержат богатый набор биологически активных веществ: флавоноиды, антоцианы, дубильные вещества, каратиноиды, тритерпеновые сапонины, сахар, органические кислоты, пектины, жирное масло, благодаря которым лекарства на основе боярышника эффективны в комплексной терапии сердечной недостаточности, функциональных расстройств сердечной деятельности, артериальной гипертонии, аритмии.

Заболевания сердечно-сосудистой системыотносят к «болезням свободных радикалов», таккак при данных заболеваниях отмечается развитиеоксидантного 
стресса и окислительные реакциистановятся основным патогенетическим факторомв развитии заболевания. Одной из самых перспективных групп биологически активных веществ, обладающей антиоксидантной активностью, являются флавоноиды. Их антиоксидантная активность объясняется двумя особенностями. Во-первых, они связывают ионы тяжелых металлов(образуя с ними устойчивые комплексы), которыеявляются катализаторами окислительных процессов. Во-вторых, фенольные соединения взаимодействуют с высокоактивными свободными радикалами, возникающими при аутоксидации, например, липидных компонентов, переводя их в малоактивные[1].

Условия нашей страны обусловливают использование во вспомогательной терапии сухих плодов некоторых лекарственных растений. Поэтому целью нашей работы явилось выяснить сохранность отдельных действующих веществ после сушки. В качестве объекта исследования использовали плоды боярышника обыкновенного, собранные в разных районах Орловской области. Количественное содержание биофлавоноидов в исследуемых ягодах и их антиоксидантную активность определяли непосредственно после сушки плодов, а также через 12 и 24 месяца хранения.

Содержание полифенольных соединений определяли в настое, отваре и спиртовом экстракте плодов боярышника обыкновенного.

Количественное определение суммарного содержания флавоноидов проводили спектрофотометрическим методом, используя реакцию комплексообразования с раствором алюминия хлорида [2]. Измерение оптической плотности проводилось на спектрофотометре «ПЭ-5300 ВИ», при длине волны410 нм в кюветах с толщиной слоя 10 мм.В качестве стандартного образца использовали ГСО кверцетина. Полученный результат является усредненным аналитическим откликом всех фенольных соединений, содержащихся в объекте анализа.

Оценку антиоксидантной активности разных препаративных форм боярышника обыкновенного определяли по методике Н.И. Ярован, Н.А. Комисаровой [3].

Результаты определения полифенольных соединений в настоях, отварах и экстрактах плодов боярышника обыкновенного представлены в таблице 1. 
Таблища 1

Суммарное содержание полифенольных соединений в плодах боярышника обыкновенного разных сроков хранения, в пересчете на квериетин, мг квериетина / $2 \pm \Delta(\mathrm{Sr}), n=6, P=0,95$

\begin{tabular}{|c|c|c|c|c|c|c|}
\hline \multirow{2}{*}{ место сбора сырья } & \multicolumn{3}{|c|}{$\begin{array}{c}\text { Орловский район, } \\
\text { Орловская область }\end{array}$} & \multicolumn{3}{c|}{$\begin{array}{c}\text { Сосковский район, } \\
\text { Орловская область }\end{array}$} \\
\hline \multirow{2}{*}{$\begin{array}{c}\text { препаративныефор } \\
\text { мы }\end{array}$} & \multicolumn{3}{|c|}{ содержание флавоноидов (в пересчете на кверцетин, мг/г) } \\
\cline { 2 - 7 } & $\begin{array}{c}\text { после } \\
\text { сушки }\end{array}$ & $\begin{array}{c}\text { через } 12 \\
\text { месяцев } \\
\text { хранения }\end{array}$ & $\begin{array}{c}\text { через } 24 \\
\text { месяца } \\
\text { хранения }\end{array}$ & $\begin{array}{c}\text { После } \\
\text { сушки }\end{array}$ & $\begin{array}{c}\text { через } 12 \\
\text { месяцев } \\
\text { хранения }\end{array}$ & $\begin{array}{c}\text { через } 24 \\
\text { месяца } \\
\text { хранения }\end{array}$ \\
\hline настой & $2,4 \pm 0,18$ & $2,3 \pm 0,13$ & $2,1 \pm 0,14$ & $2,9 \pm 0,17$ & $2,8 \pm 0,16$ & $2,7 \pm 0,20$ \\
\hline отвар & $3,1 \pm 0,09$ & $2,9 \pm 0,13$ & $2,5 \pm 0,16$ & $3,4 \pm 0,18$ & $3,3 \pm 0,22$ & $2,8 \pm 0,19$ \\
\hline экстракт & $6,8 \pm 0,23$ & $6,5 \pm 0,12$ & $6,3 \pm 0,13$ & $4,3 \pm 0,16$ & $4,1 \pm 0,15$ & $4,9 \pm 0,35$ \\
\hline
\end{tabular}

Из анализа данных таблицы 1 следует, что всепрепаративные формы плодов боярышника обладают достаточно высоким содержанием флавоноидов,причем в экстрактах содержание флавоноидов в 2 раза выше, чем в отварах и настоях. Полученные значения хорошо коррелируют с литературными данными [2].В плодах после хранения в течение 12 и 24 месяцев содержание данных веществ уменьшается, но не значительно, в среднем на 3-5\%. Таким образом, хранение плодов боярышникав течении 12 - 24 месяцев существенно не снижает содержание флавоноидов.

Антиоксидантную активность приготовленных препаративных форм боярышника определяли по уровню малоновогодиальдегида в модельных системах перекисного окисления липидов.

Для изучения антиоксидантной активности различных препаративных форм боярышника было приготовлено 10 систем, в каждую из которых (кроме контрольной) вводилась определенная препаративная форма боярышника. В каждой системе определяли уровень перекисного окисления липидов по содержанию малоновогодиальдегида после взаимодействия с тиобарбитуровой кислотой. Результаты проведенных исследований представлены в таблице 2.

Таблища 2

Содержание МДА в модельных системах перекисного окисления липидов с добавлением разных препаративных форм плодов боярышника обыкновенного разных сроков хранения, ед. опт.пл.)

\begin{tabular}{|c|c|c|c|c|}
\hline \multirow{2}{*}{$\begin{array}{c}\text { препаративныефо } \\
\text { рмы }\end{array}$} & \multicolumn{3}{|c|}{ антиоксидантная активность(ед. опт.плот.) } \\
\cline { 2 - 4 } & после сушки & $\begin{array}{c}\text { через 12 месяцев } \\
\text { хранения }\end{array}$ & $\begin{array}{c}\text { через 24 месяца } \\
\text { хранения }\end{array}$ & \multirow{2}{*}{ контроль } \\
\hline настой & 0,071 & 0,152 & 0,198 & \multirow{2}{*}{0,208} \\
\hline отвар & 0,064 & 0,123 & 0,168 & \\
\hline экстракт & 0,022 & 0,081 & 0,114 & \\
\hline
\end{tabular}

* В таблице представлены средние значения шести измерений.

Показано, что всеисследуемые препаративные формы плодов боярышника обладают антиоксидантной активностью. Антиоксидантная активность 
сохраняется после 12 и 24 месяцев хранения. Однако анализ полученных результатов по изучению антиоксидантной активности плодов боярышника показал, что наиболее активной препаративной формой являются отвар и экстракт боярышника. При этом наибольшим антиоксидантным действием плоды боярышника обладают в первый год сбора. Сушеные плоды могут быть рекомендованы для использования в изготовлении настоек боярышника обыкновенного, с возможным применениемв качестве препаратов адаптогенного действия.

Таким образом, данный метод изучения антиоксидантной активности можно использовать в скрининговых исследованиях лекарственных растений и препаратов на их основедля сравнительных исследований по установлению антиоксидантной активности растительных иприродных объектов.

\section{***}

1. Хасанова С.Р., Плеханова Т.И., Гашимова Д.Т., Галиахметова Э.Х., КлышЕ.А. Сравнительное изучение антиоксидантной активности растительных сборов // Ветник ВГУ, Серия: Химия. Биология. Фармация, 2007, № 1. С.163-166.

2. Денисенко Т.А., Вишникин А.Б., Цыганок Л.П. Спектрофотометрическое определение суммы фенольных соединений в растительных объектах с использованием хлорида алюминия, 18-молибдодифосфата и реактива Фолина-Чокальтеу //Аналитика и контроль, 2015. T. 19. №4. С. 373-380.

3. Патент РФ №2013106281/12.08.2014. Способ оценки антиоксидантной активности растительного сырья из сабельника болотного (ComarumPalustre L.)// Патент России №2013106281. 2014. Бюл. №33/ Н.И. Ярован, Н.А. Комиссарова, М.Х. Гумаров - Орел: ФГБОУ ВПО Орел ГАУ, 2012. 